\title{
Lone parents: unemployed or otherwise engaged?
}

\author{
Laura Davies* \\ University of Leeds
}

\begin{abstract}
This paper examines change and continuity in policy approaches to supporting lone parent families since 1997 . The paper considers whether re-categorizing those lone parents not engaged with the labour market as 'unemployed' reopens old debates about who deserves financial support from the state. With lone parents placed in the 'potential worker' category the influence of a moral position advocating the inherent 'goodness' of an engagement with the paid labour market and the private nature of parental caring responsibility is explored. Some potential problems with the focus on employment are highlighted, in particular the specific challenges that lone parents may face when attempting to combine paid work with caring responsibilities.
\end{abstract}

Keywords: welfare to work; lone parents; conditionality; ethics of care.

\section{Introduction}

This paper explores recent welfare reforms and considers how they relate to the specific circumstances of lone parent families in the UK. Of the two million lone parent families in the UK, 92 per cent are headed by women (ONS, 2012) with 91 per cent of lone parents not sharing child care responsibilities equally with their child(ren)'s other parent (Peacey and Hunt, 2008). The paper identifies the ways in which these factors are ignored as lone parents are increasingly conceptualised by both the Conservative and Labour parties as workless or unemployed rather than legitimately standing outside of the paid labour market as a result of their caring responsibilities. Work is conceptualised in political rhetoric as the key duty of responsible citizens with the welfare reform agenda clearly focussed on moving lone parents into the paid labour market as unemployment is portrayed as a behavioural problem (Bowring, 2000).

The approach suggests that lone parent unemployment is a significant problem, especially in relation to child poverty, with the (re)engagement of lone parents in paid employment posited as a key solution. However, 57.2 per cent of lone parents are already in paid work, an increase of 13 percentage points since 1997 . In households headed by a lone parent raising a child aged between 11 and 15, 71 per cent are in paid work (Gingerbread, 2012). The relationship between paid work and poverty is not straightforward with lone parent families having twice the rate of poverty of couple families: even when in full time work the poverty rate for lone parents is 19 per cent 
(ibid.). This data suggests that rather than unemployment per se being the cause of lone parent poverty with a simple focus on paid work as the 'solution', lone parent households have specific needs and face specific challenges with the problem of resourcing the household on a single income a significant challenge. This article argues that presenting a discourse in which lone parents are deemed to be responsible for their own financial circumstances represents an agenda based on the individualisation of social risks (Ferge, 1997).

\section{New Labour: policies on work and the family}

Prior to election in 1997, New Labour had focussed on developing policies which would persuade voters that the Party would reward hard work and act in ways that would discourage citizens from remaining on out-of-work benefits (Page, 2009: 154). The focus on employment in New Labour's later policy developments was intended to restructure the welfare state around paid work by changing cultures amongst recipients and administrators of welfare and removing 'passivity' from the old system (DSS, 1998; 23-24; Stepney et al., 1999). A focus on creating policy instruments to provide in-work support had a number of broad aims: to increase the margin between incomes out of work and in work; to decrease in-work poverty; to assist households to have at least one adult in employment and to complement active labour market policies by making work a more financially attractive option (Bennett and Millar, 2005; 31-32).

In their first budget the New Deal was introduced setting out the model for future active labour market policies (Theodore, 2007: 928). Welfare reform became a central plank of attempts to set out the direction for New Labour (Driver, 2004: 31) indicating a behavioural turn in welfare policy making. Reports were published which focussed on the desirability of promoting inclusion and breaking the cycle of disadvantage through increasing engagement with paid work (DSS, 1999). Lone parents were one of the key groups to be targeted by these activation policies (Millar, 2008) as part of New Labour's drive to tackle the intergenerational transmission of deprivation (Deacon, 2002). The policy focus had now shifted from one in which the breadwinner model exonerated mothers from the requirement to seek paid work towards an adult worker model in which all working age adults had a duty to engage with the paid labour market (Lewis, 2002).

The 'problem' of welfare dependency was to be tackled by making receipt of welfare benefits conditional on a (non negotiable) agreement from the recipient that they were actively seeking work or taking steps to improve their employment prospects. Thus behavioural conditionality was enacted with welfare benefits or services being given on condition that the recipient behaves in a particular way and/or adheres to a predefined rule or rules (Standing, 2011: 27). Central to the welfare to work approach was the focus on the labour market itself as a source of protection from income insecurity (Breitkreuz, Williamson and Raine, 2010: 44) and the idea that users of welfare state services should be regarded as reflexive agents (Redmond, 2010). Some of the specific policies targeted towards encouraging lone parents to take up paid employment included in-work financial support such as the tax credit schemes to compensate for labour market disadvantage, subsidising childcare costs and subsidising those with child care responsibilities in recognition that they may be unable to work long hours or manage long commuting times (Bennett and Millar, 2005).

Later, the publication of the Labour commissioned Freud report on "the future of welfare to work" (2007) recommended increases in conditionality and support for those in receipt of welfare, opening up these areas of work to contractors in the private 
sector and proposing the introduction of a single system of working age benefits (Freud, 2007). This was followed a year later by Gregg's (2008) report to the DWP setting out his ‘vision' for conditionality and heavily influenced by Gregg's view that the welfare state circa 1994 did not adequately meet the criteria of being "progressive, efficient and coherent" (Gregg, 2008: 5). Recommendations made therein were echoed and supported by further Green Papers. (DWP, 2008a; DWP, 2008b) and by the end of 2008 Labour's welfare reform for lone parents was underway.

These steps represented the first time that the eligibility of lone parents to the assistance set out in the 1948 National Assistance Act was restricted (Haux, 2010: 1). The phased reduction in the age of youngest resident child required to remain eligible for Income Support began in October 2008 reducing the age to 12 and by October 2010 only lone parents with a child under the age of seven would remain in the Income Support claimant group (DWP, 2007: 14). All others (who were not assessed as being eligible for disability related benefits, for which tightening of eligibility was also occurring) were transferred to Job Seekers Allowance and required to engage with its job search requirements (Welfare Reform Act, 2009).

\section{Conservative and Labour consensus on the direction of welfare reform}

In 2009, Theresa May, then Shadow Minister for Work and Pensions, had signalled her parties support for New Labour's welfare reform bill at the second reading, although she suggested that the Conservative Party would extend its conditions (May, 2009). This level of agreement on welfare is striking, although the specifics of the approaches had some key differences, in particular, the emphasis from the Conservatives on 'at home' parenting for pre-school children contrasting with Labour plans for lone parents to engage with Work Focussed Interviews when their youngest child reached one (Haux, 2011: 152). However, more recent proposals to introduce a "streamlined" benefit system in the form of the Universal Credit include proposals that lone parents with children over the age of one will be expected to "keep in touch" with their local Jobcentre and will be penalised if they fail to do so (DWP, 2010: 24).

By the 2010 election campaign, the message from the outgoing New Labour Government was clear: "tough choices" would need to be made to "increase fairness and work incentives" (The Labour Party Manifesto, 2010, 0:6) and "all those who can work will be required to do so" (The Labour Party Manifesto, 2010, 2:2). Responsibility would be "the cornerstone of our welfare state" (The Labour Party Manifesto, 2010: $2: 3)$ and, if re-elected, Labour promised to "consult on further reforms to simplify the benefits system and make sure it gives people the right incentives and personal support to get into work and progress in their jobs" (ibid.). In addition, Labour proposed to continue to investigate the possibility of introducing a single working age benefit to avoid the need to move between benefits as circumstances change (DWP, 2008a).

Much of the Conservative Party's welfare reform proposals were based on reducing welfare dependency, underpinned by the assumption that this would reduce poverty (Lister and Bennett, 2010). Welfare to work would be delivered via the Work Programme which would include all people of working age not in paid work. This would abolish the long standing bifurcation between the unemployed and those exempt from work requirements, such as disabled people, those with long term ill health and lone parents, and would leave only a very small number of disabled people eligible for ongoing out of work support (Lister and Bennett, 2010). Of particular significance for lone parents was the intention to end the couple penalty in the tax credit system signalling that "we value couples and the commitment that people make when they get married" (The Conservative Party Manifesto, 2010: 41) in line with the Conservative 
Party view on the "disastrous" rise in family breakdown (Conservative Party, 2008: 9). Both parties proposed the attachment of tightening conditionality to claims for out of work benefits with Conservative Party recommendations advocating the implementation of time limits and sanctions for non compliance with work requirements (Conservative Party, 2008). Labour made similar proposals, with those unemployed for two years guaranteed a job placement which would be mandatory, with benefits cut as a sanction for failure to engage (The Labour Party Manifesto, 2010: $2: 3)$.

\section{Changing attitudes to unemployment}

The image of unemployment as one of a struggle for dignity against the trials of involuntary unemployment has shifted towards a rhetoric of voluntary unemployment, dependency and scrounging (Standing, 2002: 156) with a focus on an ethic of selfresponsibility (Bauman, 1993). For the designers of the welfare state, "the idea of entitlement to benefit was meant to undercut any notion that the better-off were doing the worse-off a good turn...[but] there is a much greater understanding today that what people need is the chance to provide for themselves" (Commission on Social Justice, 2000: 57. Emphasis in original). The shift away from rights based welfare models impacts on the development of behavioural approaches as desert can be evaluated according to individual obedience to moral norms (Dean, 2007: 4). Approaches which focus on opportunity rather than outcome shift responsibility to the individual reducing support for universal welfare provision. This neo-liberal paradigm in which poverty becomes the fault of the poor through their failure to either manage risk or behave responsibly (Dean, 2007) underpins the development of increasingly conditional approaches to welfare. The economic assumption that unemployment is a supply side phenomenon underpins welfare and employment policies that focus on the up-rating of individual skills and employability (Driver, 2004; Theodore, 2007) and lends support to behaviourally coercive strategies: if unemployment is the fault of the individual then there is a powerful argument to support coercive elements in welfare conditionality.

\section{Conditionality or welfare rights?}

In the UK, engagement with the notion of welfare rights has been largely in the shape of a welfare 'safety net' with elements of conditionality evident in welfare models throughout the twentieth century (Dean, 2007). Conditional approaches to welfare are linked to behavioural economics and libertarian paternalism in which it is presumed that people need to be steered towards making the right choice: this element of compulsion is necessary to ensure that an acceptable choice is made (Standing, 2011: 27). Behavioural economics, unlike neo-classical approaches which assume rational economic behaviour, is an approach which takes into account social and psychological factors in decision making (NEF, 2005). This approach also advocates the importance of 'making a commitment' which can be seen as justification for a contractual approach to welfare provision (ibid.). After the 2010 election the Coalition government established a 'nudge unit', (more formally known as the Behavioural Insight Team) guided by Thaler, a key writer on libertarian paternalism in the US (see Thaler and Sunstein, 2009), to examine how these principles could be used in the UK. The Conservative's Universal Credit is explicitly designed to "produce positive behavioural effects" (DWP, 2010c: 2) and, for lone parents, will significantly widen the financial gap between working and non working lone parent households by incentivising paid work (Browne, 2012: 6). 
Focussing on conditionality weakens social solidarity by introducing and/or entrenching the distinction between the deserving and undeserving (Standing, 2011: 35) and creating divisions that weaken support for welfare provisions (McKee and Stuckler, 2011). Unemployment is then seen to be caused by a lack of motivation or employability rather than a lack of employment opportunities (Crisp, 2008: 173) with individuals having a moral obligation to seek work (ibid.). Dean (2007) argues that this focus on responsibility represents an individualisation of risk (Beck, 1992); a significant shift from earlier welfare models conceptualising unemployment as an "identified disservice caused by society" (Titmuss, 1967/2000: 44) for which welfare benefits provided "partial compensation" (ibid.). Although the debates around the deserving and undeserving poor have a long history (Bagguley and Mann, 1992), the strength of the distinction between those deemed to deserve support and those who do not has increased in line with rhetoric which emphasises individual responsibility. A lack of employment opportunities is thus recast as an individualised problem of worklessness as the social is individualised (Ferge, 1997).

Churchill (2012) has argued that a primary function of social policies is not to respond to need but to promote particular sets of values and encourage certain types of socially desirable behaviour. As discussed previously, the New Labour government embraced the centrality of paid work as a key indicator of social inclusion with labour market insertion policies reflecting the shift from a breadwinner to an adult worker model (Lewis, 2002). Policy responses in the form of active labour market programmes were focussed on effecting behavioural change through a combination of "help, advice and guidance" (Skevik, 2005: 51). Individuals positioning themselves outside of the paid labour market were increasingly regarded as exhibiting a behavioural problem with an engagement with paid work deemed to play an essential part in the creation of self worth, economic participation, usefulness and social inclusion (Bowring, 2000: 310) as well as good health (Black, 2006). The approach appeared to be informed by the idea that engaging in paid employment offers additional benefits such as status, social interaction and participation in the norms of society alongside increased income (Perkins, 2007: 17). Welfare debates are then framed by a focus on the personal with unemployment conceived of in individualistic and behavioural terms (Peck and Theodore, 2000; Crisp, 2008). More recently, political leaders from the three main parties (see Cameron, 2011; Clegg, 2011; Miliband, 2011) have all argued that long term unemployment is a problem associated with a lack of individual responsibility.

However, the focus on supply side explanations for unemployment and worklessness continue to represent a flawed analysis and lack consideration of the impact of demand side concerns including a lack of employment opportunities and quality (see for example Theodore, 2007) an element of the welfare reform discourse that is especially troubling in the current economic climate. A key difficulty remains with these proposals because, as Fothergill (2010) argues, almost all of New Labour's welfare reforms as well as those later implemented by the Coalition, are underpinned by the assumption that, in order to secure employment, all that is necessary is a commitment from the unemployed person to look for it. Addressing the Conservative Party Conference in spring of 2011 lain Duncan Smith suggested that it was "not the absence of jobs that's the problem - it's the failure to match the unemployed to the jobs there are" (Duncan Smith, 2011) This emphasis on individual responsibility is also explicit in shadow work and pensions secretary Liam Byrne's (2012) recent writing for The Guardian, where he suggests that a key strategy for tackling unemployment lies in a commitment from the unemployed to "work hard to find a job". The Office for National Statistics released data in December 2011 rather challenging this view, indicating that 2.64 million people were unemployed with just 455,000 vacancies in the three months to November 2011 (ONS, 2011). 


\section{p. 21. Lone parents: unemployed or otherwise engaged?}

\section{Gendered patterns of employment}

The normalisation of maternal employment appears to have been a key factor in making employment focussed welfare reforms for lone parents politically palatable. Changing employment markets have meant that women's dependency on a husbands' income has declined amid increasing labour market participation rates of mothers. Increasing levels of maternal employment from the 1970s onwards appear to have given support to the idea that combining paid work with motherhood is both possible and desirable. By 2002 four in six mothers of dependent children were in paid employment, up from one in six in 1951 (Hansen et al., 2006). Since the 1960s feminist concerns with the importance of women's ability to choose between paid work and domestic caregiving have developed into an acceptance that working motherhood could and should be the norm (Mahon, 2009: 188). This shift has been demonstrated in research by Himmelweit and Sigala (2004) who found that the belief that young children were not disadvantaged by their mother being in employment became more common alongside rising rates of maternal employment. However, the employment rates of lone mothers had fallen in the period from the late 1970s to the 1990s (Gregg and Harkness, 2003) despite increases in the wider employment rates of mothers with dependent children (Hansen et al., 2006; Gornick and Meyers, 2007), thus suggesting that something in their circumstances was deterring lone parents from engaging with the paid labour market during that time. By 2005 the employment rate of lone parents, using New Labour's definition of working one hour or more per week, was 58 per cent with employment rates rising alongside the rising age of youngest child (Lyon et al., 2005; see also Haux, 2010: 6). Economic equality through labour market participation has come to be regarded as central to women's independence with declining attention paid to the care responsibilities of both women and men (Lewis, 2006: 433).

\section{Balancing paid work with family life}

"Reforming welfare around the work ethic" (Lister, 1999: 234) places employment as the central duty of 'active' citizenship with caring excluded from normative definitions of 'work'. Whilst in the past the contributions made by parents as carers were recognised as socially useful and lone mothers were granted assistance on the basis of their maternal status to enable them to care for their children (Daly, 2011: 10), this has declined in recent years as entitlement to welfare without work requirements has come to be regarded as a central factor in entrenching welfare dependency (Dwyer, 2004). Being a responsible citizen is thus conflated with an engagement with paid work and has become central to welfare policy discussions across the political spectrum (see for example DSS, 1999; Freud, 2007; DWP, 2007; DWP, 2008a; DWP, 2008b; DWP, 2010a; DWP, 2010b; DWP, 2010c). The declining distinction between gendered activities of earning and caring alongside the focus on employment as a key site of women's equality status reflect a shift in public outlook and thus open up the space for policies to be developed which are employment rather than support focussed (Orloff, 2006: 231). Full-time motherhood is no longer idealised by and supported by policy except for those caring for the very youngest children. Motherhood has been reconceptualised as a component of the life course rather than a life course in its own right (Pfau-Effinger, 2005; Daly, 2011) and this may be linked to broader trends in fertility, such as declining family size.

What the work focussed rhetoric fails to address is the way in which work requirements could decrease the active parenting ability of lone parents. Although the Conservative Party earlier suggested that work requirements for lone parents would "reflect the limitations that good parenting places on the ability to work...[and they will] 
not be forced into a position where they have to work hours that are completely incompatible with good parenting" (Conservative Party, 2008: 35) later welfare reform proposals suggest that these flexibilities will be rather limited in practice and lone parents may find that paid work undermines their ability to parent as they choose (Duncan et al., 2003). Research indicates that those children who are closely monitored and supervised are less likely to engage in risk-taking behaviour (JRF, 2005) and so managing the balance between caring and earning is a particularly pertinent issue for those parenting with limited time resources. Supervisory parenting is often presented as a key measure of responsible child rearing (Cameron, 2011) with research suggesting that supervising children is central to fostering their development of self control and acceptable behaviour (Boutwell and Beaver, 2010; Lexmond et al., 2011). Key elements of supervision, such as knowing where children are, with whom and what they are doing are more difficult to execute from the workplace than the home and so present a key site of tension for working parents.

Whilst we know that lone parents and their children can face significant challenges when moving from welfare into paid employment (Millar, 2008; Millar and Ridge, 2008; Ridge and Millar, 2011), this is not currently regarded as sufficient reason to see lone parents as vulnerable or 'deserving'. There is scant recognition in policy discussion that lone parents and separated families can be vulnerable with this limited to those families in which domestic violence has taken place (see DWP, 2011). Whilst maternal mental health is noted as being central to the well being of children (Field, 2010) the pressure of combining paid work with family care lacks official recognition as a source of stress for those parenting alone, with policies disconnected from the realities of everyday family life. These factors place in question the commitment that "If you are vulnerable and in need, we will look after you. And if you hit hard times, we'll give unprecedented support." (Cameron, 2011).

The assumption of the citizen-worker as autonomous and self sufficient does not give adequate attention to the type of work that women (most lone parents are still women) often do: frequently low paid and part time (Breitkreuz et al., 2010: 48). Attempting to balance work/life in these types of employment needs to be recognised as being qualitatively different from attempts to do so in the context of 'middle-class' working patterns (Grabham and Smith, 2010: 85). It is likely that the wider benefits assumed to be a side effect of employment (Bowring, 2000; Wadell and Burton, 2006; Black, 2008) may not be available to those working in low paid and low skilled employment (Crisp, 2008: 101). We also know that lone parents in low paid or part time employment rarely escape poverty through their earnings alone (Gardiner and Millar, 2006) with additional income from tax credits, other benefits and child maintenance essential in raising household income above the poverty line (Ridge and Millar, 2011). Important research from Millar and Ridge disputed claims that paid work was the solution to lone parent family poverty, finding that financial gains were often limited especially when placed in the context of the wider practical impacts of lone mothers engaging in paid employment outside the home (Millar, 2006; Ridge, 2007; Millar and Ridge, 2008). Although benefits are having the effect of narrowing the income gap between working and workless households, the number of households living in in-work poverty exceeds those in impoverished workless households (Lexmond et al., 2011: 107). Ongoing research continues to affirm that the relationship between employment and poverty is complex for lone parent families (Ridge and Millar, 2011) and it is also known that high levels of child poverty are particularly associated with frequent household transitions in and out of the labour market (Magadi and Middleton, 2005).

Entry level employment of the type likely to be accessed by those who have been outside of the labour market for a period of time has some key characteristics that 
make it particularly challenging for lone parents to sustain. The type of employment entered after a long period outside of the labour market is often low paid; has variable, temporary, part time, long or unsociable hours; is labour intensive; low skilled and has a high staff turnover (Centre for Social Justice; 2011: 14). These same features have been identified as characteristic of 'poor quality' jobs (McCollum, 2011) with some commentators suggesting that this type of precarious insecure employment (TUC, 2008; Standing, 2011) may become a key feature of future labour markets (Clayton and Brinkley, 2011). Lone parents face additional challenges as job seekers as they need to find flexible work and source and pay for childcare in a highly uncertain labour market (Browne, 2012: 3). This low earnings power is affected by both the supply and the demand side with job entry alone not a sufficient basis on which to achieve reductions in poverty and increase social mobility, a situation that may be exacerbated further by the limited possibilities for progression for employees in smaller firms (ibid.). It is well documented that many of those leaving welfare for employment return to welfare soon after, leading to 'cycling' between work and welfare over long periods of time because sustaining employment is more likely if the job is secure and the employee well suited to it (McCollum, 2011).

\section{Conclusions}

Focussing on paid work as a key site in which to create self worth, inclusion and status (Bowring, 2000; Wadell and Burton, 2006; Black, 2008) as well as the primary duty of active citizenship emphasises the importance of employment at both the societal and individual level. The shift from policies which focussed on supporting lone mothers to those which seek to persuade and compel them to enter the paid labour market has been described as a "farewell to maternalism" (Orloff, 2006: 230) Alongside the normalisation of maternal employment the conditions are created for policies designed to influence the employment behaviour of lone parents couched in the language of the 'goodness' of work itself. Indeed, engagement in paid work has been conceptualised as a key parental duty owing to the interpretation of data which suggests that poverty, related to non engagement with paid work, has numerous negative impacts on child well being and their long term prospects. Arguments that workless households tend to create cycles of deprivation (CSJ, 2007; Conservative Party, 2008) are based on an analysis that is flawed by its lack of consideration of the place of care, I suggest, largely due to the difficulties in measuring care as an economic value.

This normalization of maternal employment and of parenting in one parent households appear to have led to the loss of the status of lone parents as a vulnerable group in need of financial protection. Thus the space has opened up for the removal of support for lone parent households through the policy process and consequent redefinition of lone parenthood as a personal experience rather than a social 'problem" deserving of state support. Therefore the complex challenges experienced when resourcing the household and managing the care of children alone have been placed as a concern for individual parents rather than the wider community. However, feminist approaches to care identifying the work involved in caring activity (Tronto, 1989; Kittay, 2001; Williams, 2001; Bubeck, 2002, West, 2002; Williams, 2004) present a challenge to the notion that caring for children is a personal rather than a societal responsibility. In addition to the emotional elements of caring, the domestic labour involved in family life has been conceptualised as a "second shift" (Hochschild, 1990) and "the work outside the work" (Breitkreuz et al., 2010) giving weight to the contention that balancing paid work with care is challenging (Wiggan, 2010).

This ethic of care and responsibility is largely disregarded by a policy framework which sees an engagement with paid work as a central duty of active citizenship. 
Rather than a simple focus on moving lone parents into paid work, recognition of the work they do in raising their children could enable more parents to combine the two roles more effectively when they are ready to join the labour market. Using behavioural approaches which seek to encourage and/or compel lone parents to enter the labour market by invoking a moral standpoint are likely to pose particular problems where they challenge the moral view of parents themselves and prevent them from making choices about how best to care for their families. It seems likely that addressing some of the demand side issues by improving the availability of decent work (Women's Budget Group, 2010) and improving employment sustainability and job retention (Millar and Bennet, 2005) have a central part to play in enabling lone parents to combine their responsibilities to their children and to paid work. The structure of the Conservative's flagship Work Programme gives some consideration to job sustainability, with welfare to work providers able to claim sustainment payments for clients they have placed in work (DWP, 2011b) and the Universal Credit allows for school hours working for lone parents of children aged between five and twelve (DWP, 2011c). However, enforcing work focussed welfare reforms during recession remains problematic and for lone parents these problems may also be compounded by other factors in their labour market disadvantage and the disproportionate impact on women of the current round of government spending cuts (Women's Budget Group, 2010).

\section{Acknowledgements}

An earlier version of this paper was presented at the Conference of the Social Policy Association 'Bigger Societies, Smaller Governments', University of Lincoln, 2011. I would like to thank members of the audience at the presentation for their helpful feedback and comments.

* Correspondence address: Laura Davies, School of Sociology and Social Policy, University of Leeds, Leeds, LS2 9JT. Email: L.Davies@leeds.ac.uk.

\section{References}

Bagguley, P. and Mann, K. (1992) Idle thieving bastards: scholarly representations of the underclass. Work, Employment and Society, 1992, 6, 1, 113-126.

Bauman, Z. (1993) Postmodern Ethics. Oxford: Blackwell.

Beck, U. (1992) Risk Society: Towards a new modernity. London: Sage.

Beveridge, W. (1942) Social Insurance and Allied Services. London: HMSO.

Black, C. (2008) Working for a Healthier Tomorrow. London: TSO.

Boutwell, B. B. and Beaver, K. M. (2010) The intergenerational transmission of low selfcontrol.' Journal of Research in Crime and Delinquency, 47, 2, 174-209.

Bowring, F. (2000) Social exclusion: limitations of the debate. Critical Social Policy, 2000, 20, 3, 307-330.

Breitkreuz, R. S., Williamson, D. L. and Raine, K. D. (2010) Dis-integrated policy: welfare-to-work participants experiences of integrating paid work and unpaid family work. Community, Work and Family, 2010, 13, 1, 33-69.

Browne, J. and Levell P. (2010) The distributional effect of tax and benefit reforms to be introduced between June 2010 and April 2014: a revised assessment London: Institute for Fiscal Studies.

Browne, J. (2012) The Impact of Austerity Measures on Households with Children. London: Family and Parenting Institute. 
Bubeck, D. C. (2002) Justice and the Labour of Care, in: F. Kittay and E. K. Feder (eds.) (2002) The Subject of Care. Feminist Perspectives on Dependency. New York: Rowman and Littlefield.

Byrne, L. (2012) A William Beveridge for this century's welfare state.

http://www.guardian.co.uk/commentisfree/2012/jan/02/beveridge-welfare-statelabour-revolution

Cameron, D. (2011) PM's speech on the Welfare Reform Bill 17 February 2011. http://www.number10.gov.uk/news/pms-speech-on-welfare-reform-bill/

Cameron, D. (2011) PM's speech on the fightback after the riots.

http://www.number10.gov.uk/news/pms-speech-on-the-fightback-after-the-riots/

Centre For Social Justice (2007) Breakthrough Britain. London: Centre for Social Justice.

Centre for Social Justice (2011) Creating Opportunity, Rewarding Ambition: The value of entry level employment A policy report by the Employment Working Group. London: Centre for Social Justice.

Churchill, H. (2011) Parental rights and responsibilities: Analysing policy and service user perspectives. Bristol: Polity Press.

Clayton, N. and Brinkley, I. (2011) Welfare to What? Prospects and challenges for employment recovery. London: The Work Foundation.

Clegg, N. (2011) Nick Clegg's speech to Spring Conference. http://www.libdems.org.uk/speeches detail.aspx?title=Nick Clegg

Commission on Social Justice (2000) What is social justice? in: C. Pierson and F. G. Castles (2000) The Welfare State Reader. Cambridge: Polity Press.

Conservative Party (2008) Work for Welfare: REAL welfare reform to make British poverty history. London: The Conservative Party.

Crisp, R. (2008) Motivation, morals and justice: discourses of worklessness in the welfare reform green paper. People, Place and Policy Online, 2, 3, 172-185.

Daly, M. (2011) What Adult Worker Model? A Critical Look at Recent Social Policy Reform in Europe from a Gender and Family Perspective. Social Politics, 18, 1, 123.

Deacon, A. (2002) Welfare reform and poor families in the USA in: A. Carling, S. Duncan and R. Edwards (2002) Analysing Families: Morality and rationality in policy and practice. London: Routledge.

Dean, H. (2007) The ethics of welfare-to-work. Policy and Politics, 35, 4, 573-590.

Dean, H. (2007) Social Policy and Human Rights: Re-thinking the Engagement. Social Policy and Society, 7, 1, 1-12.

Driver, S. (2004) North Atlantic drift: welfare reform and the Third Way politics of New Labour and the New Democrats in: S. Hale., W. Leggett and Martell, L. (2004) The Third Way and beyond: criticisms, futures, alternatives. University Press: Manchester.

DSS (1999) The Changing Welfare State: Opportunity for all. Tackling poverty and social exclusion. London: Stationery Office.

Duncan, S., Edwards, R., Reynolds, T. and Alldred, P. (2003) Motherhood, Paid Work and Partnering: Values and Theories. Work, Employment and Society, 17, 2, 309330.

DWP (2007) Ready for work: full employment in our generation. Norwich: HMSO.

DWP (2008a) Raising expectations and increasing support: reforming welfare for the future. Richmond: OPSI.

DWP (2008b) No one written off: reforming welfare to reform responsibility. Kew: OPSI.

DWP (2010a) The Work Programme: Invitation to Tender. http://www.dwp.gov.uk/

DWP (2010b) The Work Programme Prospectus: November 2010. www.dwp.gov.uk/docs/work-prog-prospectus-v2.pdf

DWP (2010c) 21st Century Welfare. http://www.dwp.gov.uk/docs/21st-centurywelfare-response.pdf 
DWP (2011) Strengthening families, promoting parental responsibility: the future of child maintenance. http://www.dwp.gov.uk/docs/strengthening-families.pdf

DWP (2011b) The Work Programme http://www.dwp.gov.uk/docs/the-workprogramme.pdf

DWP (2011c) Universal Credit Policy Briefing Note 11 Extending conditionality under Universal Credit to working claimants: setting a new conditionality threshold http://www.dwp.gov.uk/docs/ucpbn-11-conditionality-threshold.pdf

Dwyer, P. (2004) Creeping conditionality in the UK: from welfare rights to conditional entitlements. Canadian Journal of Sociology, 29, 2, 265-287.

Ferge, Z. (1997) The changed welfare paradigm: the individualization of the social. Social Policy \& Administration, 31, 1, 20-44.

Field, F. (2010) The Foundation Years: Preventing poor children becoming poor adults The Report of the Independent Review on Poverty and Life Chances. London: HM Government.

Fothergill, S. (2010) Welfare to work: time for a rethink. People, Place and Policy Online, 4, 1, 3-5.

Freedland, M. and KING, D. (2005) Client contractualism between the Employment Service and jobseekers in the United Kingdom in: E. Sol and M. Westerveld (eds.) Contractualism in Employment Services. The Hague: Kluwer.

Freud, D. (2007) Reducing dependency, increasing opportunity: options for the future of welfare-to- work. An independent report to the department of work and pensions. Leeds: HMSO.

Gardiner, K. and Millar, J. (2006) How low-paid employees avoid poverty: An analysis by family type and household structure. Journal of Social Policy, 35, 3, 351-369.

Gingerbread (2012) http://www.gingerbread.org.uk/content.aspx?CategorylD=365

Gornick, J. C. and Meyers, M. K. (2007) Institutions that Support Gender Egalitarianism in Parenthood and Employment. www.havenscenter.org/realutopias/2006

Grabham, E. and Smith, J. (2010) From social security to individual responsibility (Part Two): Writing off poor women's work in the Welfare Reform Act 2009. Journal of Social Welfare and Family Law, 32, 1, 81-93.

Gregg, P. and Harkness, S. (2003) Welfare Reform and the Employment of Lone Parents in: R. Dickens, P. Gregg and J. Wadsworth (eds.) (2003) The Labour Market Under New Labour. Basingstoke: Palgrave MacMillan.

Halpern, D., Bates, C., Mulgan, G., Aldridge, S., Beales, G. and Heathfield, A. (2004) Personal Responsibility and Changing Behaviour: the state of knowledge and its implications for public policy. London: Cabinet Office, Prime ministers Strategy Unit.

Hansen, K., Joshi, H. and Verropoulou, G. (2006) Childcare and mothers' employment: approaching the millennium. National Institute Economic Review, 195, 1, 84-102.

Haux, T. (2010) Activating lone parents: Applying alternative approaches to the British case. Paper presented to 6th International Policy and Research Conference on Social Security Luxembourg 29/9/2010 - 1/10/2010.

Haux, T. (2011) Lone parents and the Conservatives: anything new? in: C. Holden, M. Kilkey and G. Ramia (eds.) (2011) Social Policy Review 23 Analysis and debate in social policy. Bristol: Policy Press.

Himmelweit, S. and Sigala, M. (2004) Choice and the relationship between identities and behaviour for mothers with pre-school children: Some implications for policy from a UK study. Journal of Social Policy, 33, 3, 455-78.

JRF (2005) Findings. Parental supervision: the views and experiences of young people and their parents. York: JRF.

Kittay, E. F. (2001) A Feminist Ethic of Care Meets the New Communitarian Family Policy. Ethics, 111, 3, 523-547. 
Lewis, J. (2002) The Adult Worker Model, in: A. Carling, S. Duncan and R. Edwards (eds.) Analysing Families: Morality and Rationality in Policy and Practice. London: Routledge.

Lewis, J. (2006) Work/family reconciliation, equal opportunities and social policies: the interpretation of policy trajectories at the EU level and the meaning of gender equality. Journal of European Social Policy, 13, 3, 420-437.

Lexmond, J., Bazlgette, L. and Margo, J. (2011) The Home Front. London: Demos.

Lister, R. (1999) Reforming welfare around the work ethic: new gendered and ethical perspectives on work and care. Policy and Politics, 27, 2, 233-246.

Lister, R. and Bennett, F. (2010) The new champion of progressive ideals. Renewal.

Lister, R. (2006) Children (but not women) first: New Labour, child welfare and gender. Critical Social Policy, 26, 315-335.

Lyon, N., Mangla, J., Tait, C. and Scholes, S. (2007) Families and Children Study (FACS) 2005, Wave 7. http://www.esds.ac.uk/doc/4427/mrdoc/pdf/4427facs2005_te chnical report.pdf

Magadi, M. and Middleton, S. (2005) Britain's Poorest Children Revisited: Evidence from the BHPS 1994-2002 Research Report Three. Loughborough: Centre for Research on Social Policy.

Mahon, R. (2009) The OECD's Discourse on the Reconciliation of Work and Family Life. Global Social Policy, 9, 183-204.

May, T. (2009) A new way with benefits. http://www.guardian.co.uk/commentisfree /2009/jan/27/welfare-reform-bill-unemployment

Mccollum, D. (2011) An acceptance that it's just your lot I suppose: reflections on turbulent transitions between work and welfare. People, Place and Policy Online, 5, 3, 149-160.

Mckee, M. and Stuckler, D. (2011) The assault on universalism: how to destroy the welfare state. British Medical Journal, 343, 7973.

Miliband, E. (2011) Responsibility in 21st Century Britain, Speech at Coin Street Neighbourhood Centre, 13th June

http://www.labour.org.uk/ed-miliband-speech-responsibility,2011-06-13

Millar, J. (2008) Making work pay, making tax credits work: An assessment with specific reference to Ione-parent employment. International Social Security Review, 61, 2, 21-38.

Millar, J. and Ridge, T. (2008) Relationships of Care: Working Lone Mothers, their Children and Employment Sustainability. Journal of Social Policy, 38, 1, 103-121.

New Economics Foundation (2005) Behavioural economics: seven principles for policy makers. London: New Economics Foundation.

Office for National Statistics (2011) Labour Market Statistics, December 2011. http://www.ons.gov.uk/ons/rel/Ims/labour-market-statistics/december2011/index.html

Office for National Statistics (2012) Lone parents with dependent children.

Orloff, A. S. (2006) From Maternalism to Employment for All: State Policies to Promote Women's Employment across the Affluent Democracies' in: J. D. Levy (ed.) (2006) The State After Statism: New State Activities in the Age of Liberalization. Harvard: University Press.

Page, R. M. (2009) With love from me to you: the New Democrats, New Labour and the politics of welfare reform. Benefits, 17, 2, 149-158.

Peacey, V. and Hunt, J. (2008) Problematic Contact after Separation and Divorce. London: Gingerbread.

Peck, J. and Theodore, N. (2000) Beyond employability. Cambridge Journal of Economics, 24, 729-749.

Perkins, D. (2007) Improving Employment Participation for Welfare Recipients Experiencing Severe Personal Barriers. Social Policy and Society, 7, 1, 13-26. 
Pfau-Effinger, B. (2005) Welfare State Policies and the Development of Care Arrangements. European Societies, 7, 2, 321-347.

Poole, G. (2011) Criminal riots reveal part of British society broken and detached Press Release From The Centre For Social Justice. http://www.centreforsocial justice.org.uk/client/downloads/CSJ\%20riotsresponse\%208\%208\%2011.pdf

Redmond, G. (2010) Children's agency and the welfare state: Policy priorities and contradictions in Australia and the UK. Childhood, 17, 4, 47- 484.

Ridge, T. and Millar, J. (2011) Following Families: Working Lone Mother Families and their Children. Social Policy and Administration, 45, 1, 85-97.

Skevik, A. (2005) Women's Citizenship in the Time of Activation: The Case of Lone Mothers in Needs-Based Welfare States. Social Politics: International Studies in Gender, State and Society, 12, 1, 42-66.

Smith, D., I. (2011) Reforming our Pensions and Welfare System speech. http://www.conservatives.com/News/Speeches/2011/03/lain_Duncan_Smith_ Reforming our pensions and welfare system.aspx

Standing, G. (2002) Beyond the New Paternalism: Basic Security as Equality. London: Verso.

Standing, G. (2011) Behavioural conditionality: Why the nudges must be stopped - an opinion piece. Journal of Poverty and Social Justice, 19, 1 27-38.

Thaler, R. and Sunstein, C. (2009) Nudge: improving decisions about health, wealth and happiness. London: Yale University Press.

Theodore, N. (2007) New Labour at work: long term unemployment and the geography of opportunity. Cambridge Journal of Economics, 31, 6, 927-939.

Titmuss, R. (1967/2000) Universalism versus Selection in: C. Pierson and F. G. Castles (eds.) (2000) The Welfare State Reader. Cambridge, Polity Press.

Tronto, J. C. (1989) Women and Caring: What can Feminists Learn About Morality from Caring?' in: V. Held (ed.) (1995) Justice and Care. Essential Readings in Feminist Ethics. Boulder: Westview Press.

TUC (2008) Hard Work, Hidden Lives: The Full Report of the Commission on Vulnerable Employment. http://www.vulnerableworkers.org.uk/files/CoVE_full_report.pdf

Van Berkel, R. and Borghi, V. (2008) Review Article: The Governance of Activation. Social Policy and Society, 7, 3, 393-402.

Waddell, G. and Burton, K. (2006) Is Work Good for Your Health and Wellbeing? A review of the literature. London: TSO.

West, R. (2002) The Right to Care in: E. F. Kittay and E. K. Feder (eds.) (2002) The Subject of Care. Feminist Perspectives on Dependency. Rowman and Littlefield: New York.

Wiggan, J. (2010) Managing time: the integration of caring and paid work by lowincome families and the role of the UK's tax credit system. Policy Studies, 31, 6, $631-645$.

Williams, F. (2001) In and beyond New Labour: towards a new political ethics of care. Critical Social Policy, 21, 4, 467-493.

Williams, F. (2004) What Matters is who Works: Why Every Child Matters to New Labour. Commentary on the DfES Green Paper Every Child Matters'. Critical Social Policy, 24, 406-427.

Women's Budget Group (2010) A Gender Impact Assessment of the Coalition Government Budget. June 2010. 